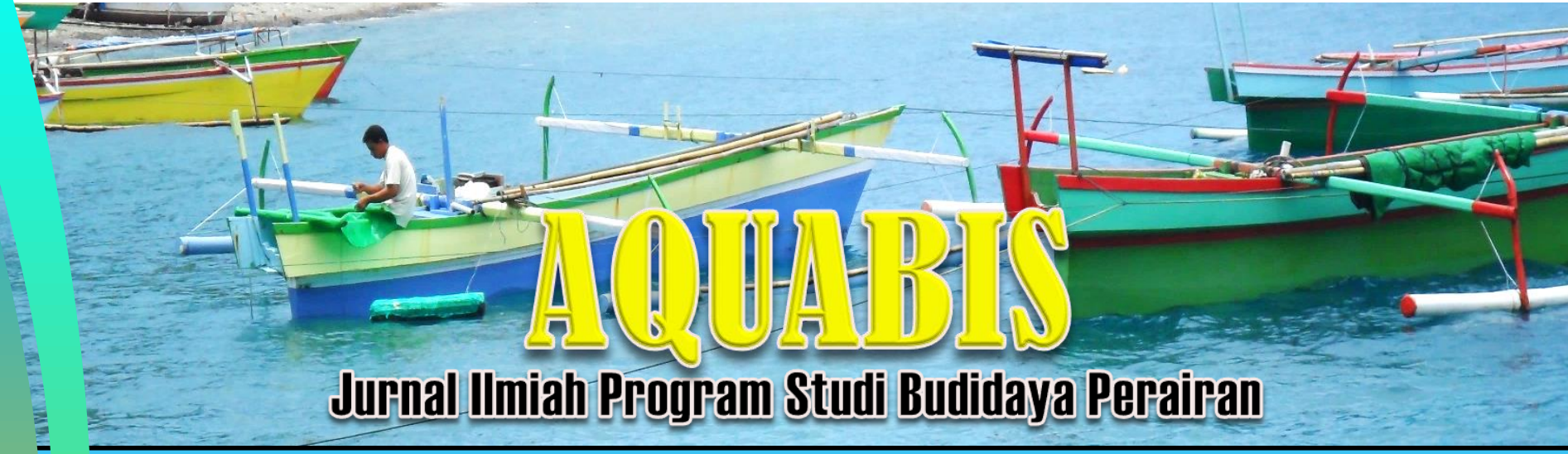

Volume 7 Nomor 2 Desember 2017

ISSN: 2301-5705

SANITASI DAN HYGIENE PADA PROSES PEMBUATAN RAMBAK IKAN BUNTAL PISANG (Tetraodon lunaris) DI UKM JAYA UTAMA KECAMATAN MAYANGAN KOTA PROBOLINGGO JAWA TIMUR

Rahyuni Syamsudin Domili 1

NILAI MANFAAT LANGSUNG EKOSISTEM TERUMBU KARANG DI TAMAN WISATA PERAIRAN PADAIDO, PAPUA

Ni'mawati Syariah 7

STRUKTUR KOMUNITAS MAKROZOOBENTOS PADA EKOSISTEM PADANG LAMUN DI PERAIRAN PANTAI LOGPON DESA MOLANTADU KABUPATEN GORONTALO UTARA.

Nurul Auliyah, Candra Masuara 13

TINGKAT KESUKAAN DAN KADAR PROTEIN ILABULO CUMI-CUMI YANG BERSUBTITUSI TEPUNG TAPIOKA

Yulianti

REHABILITASI LAHAN MANGROVE OLEH MASYARAKAT PESISIR DI DAS RANDANGAN KABUPATEN POHUWATO

Dewa Oka Suparwata

PEMBERIAN DOSIS PAKAN OTOHIME YANG BERBEDA TERHADAP PERTUMBUHAN BENIH IKAN KERAPU BEBEK (Chromileptes altivelis)

Erlansyah, Hasim, dan Mulis 33

PENGARUH PERTUMBUHAN DAN EFISIENSI PAKAN IKAN NILA GIFT (Oreochromis niloticus) DENGAN PROPORSI PROTEIN PAKAN YANG BERBEDA

Titin Liana Febriyanti 39 


\title{
PENGARUH PERTUMBUHAN DAN EFISIENSI PAKAN IKAN NILA GIFT (Oreochromis niloticus) DENGAN PROPORSI PROTEIN PAKAN YANG BERBEDA
}

\author{
Titin Liana Febriyanti
}

\author{
Program Studi Budidaya Periaran \\ Fakultas Ilmu-Ilmu Pertanian \\ Universitas Muhammadiyah Gorontalo \\ Email: titinlianaf@yahoo.com
}

\begin{abstract}
Tilapia (Oreochromis niloticus) has economic value due to high consumer demand, relatively affordable price, favorable taste and high tolerance to the environment. Constraints faced by farmers is the high feed prices because raw materials such as fish meal is still imported. So need to find alternative raw materials such as golden snail flour which has a cheap price. The purpose of this study is to analyze the proportion of the right golden snail flour in the fish feed so as to provide maximum growth rate for the seeds of tilapia gift. The experimental design used was Completely Randomized Design (RAL) consisting of 5 treatments with 3 replications. The parameters observed were growth rate and feed efficiency. The experimental results showed that the $C$ treatment $(0.19 \mathrm{~g} /$ day) was the highest growth rate and the highest feed efficiency in treatment $C$ was $88.03 \%$.
\end{abstract}

Keywords: tilapia, mas snail flour, growth rate, and feed efficiency

Abstrak

Ikan nila (Oreochromis niloticus) memiliki nilai ekonomis karena permintaan konsumen yang tinggi, harga yang relatif terjangkau, rasa yang digemari dan memiliki toleransi yang tinggi terhadap lingkungan. Kendala yang dihadapi petani adalah harga pakan yang tinggi karena bahan baku seperti tepung ikan masih di impor. Maka perlu mencari bahan baku alternatif seperti tepung keong mas yang memiliki harga yang murah. Tujuan penelitian ini adalah menganalisis proporsi tepung keong mas yang tepat dalam pakan ikan sehingga mampu memberikan laju pertumbuhan yang maksimal bagi benih ikan nila gift. Rancangan percobaan yang digunakan ialah Rancangan Acak Lengkap (RAL) yang terdiri dari 5 perlakuan dengan 3 ulangan. Parameter yang diamati adalah laju pertumbuhan dan efisiensi pakan. Hasil percobaan menunjukkan bahwa perlakuan C $(0,19 \mathrm{~g} / \mathrm{hari})$ merupakan laju pertumbuhan yang tertinggi dan efesiensi pakan tertinggi pada perlakuan C yaitu 88,03\%.

Kata Kunci: ikan nila, tepung keong mas, laju pertumbuhan, dan efisiensi pakan

\section{PENDAHULUAN}

Ikan nila (Oreochromis niloticus) merupakan ikan yang memiliki nilai ekonomis yang penting, karena memiliki rasa yang enak, harga yang relatif terjangkau, serta ikan ini memiliki toleransi yang tinggi terhadap lingkungan yang fluktuatif. Di Indonesia ikan nila juga dikembangkan sebagai komoditas ekspor. Tingginya permintaan ikan konsumsi membuat para pembudidaya banyak melakukan rekayasa dalam pembudidayaan ikan ini, salah satunya yaitu dalam pembuatan pakan.
Menurut (Craig, 2009) kualitas dan kuantitas nutrien yang baik merupakan dasar untuk menghasilkan ikan yang sehat dan berkualitas. Untuk itu, dalam pembuatan pakan diperlukan formulasi yang tepat sesuai dengan kebutuhan nutrien ikan nila. Selain kandungan protein, komposisi yang lain pun harus disesuaikan kebutuhan ikan. Pakan sangat berpengaruh terhadap pertumbuhan ikan dan merupakan bagian terbesar dari biaya operasional, yaitu 40 - 50\% dari total biaya produksi (Craig, 2009). Besarnya biaya operasional dalam pembuatan pakan disebabkan oleh tingginya harga pakan komersial yang menggunakan tepung ikan 
sebagai bahan baku utama yaitu tepung ikan. Tingginya harga tepung ikan di Indonesia karena permintaan yang meningkat dan terbatasnya bahan baku yang tersedia.

Kendala yang dialami pembudidaya yaitu tingginya harga pakan/pellet komersil, maka produsen perlu mencari bahan baku alternatif untuk menggantikan tepung ikan. Salah satu sumber protein hewani dalam pakan ikan yang dapat menjadi pengganti yaitu tepung dari keong mas (Pomacea caniculata). Penelitian ini dilakukan dengan tujuan mengetahui proporsi tepung keong mas yang maksimal dalam pakan terhadap laju pertumbuhan ikan nila gift.

\section{METODE PENELITIAN}

\section{Alat dan Bahan}

Alat yang digunakan adalah akuarium sebanyak 15 buah, perangkat aerator, timbangan analitik, DO meter, $\mathrm{pH}$ meter, serokan, baskom, ember, kamera, dan alat tulis. Sedangkan bahan yang digunakan adalah ikan nila gift, berukuran $4 \mathrm{~cm}$ dengan rata-rata berat \pm 3 gram sebanyak 300 ekor. Pakan buatan dibuat dari bahan-bahan sebagai berikut: tepung ikan, tepung keong mas, tepung kedelai, tepung tapioka, tepung jagung, minyak ikan, minyak jagung, dan premix.

\section{Rancangan Percobaan}

Penelitian dilakukan dengan metode Rancangan Acak Lengkap (RAL) yang terdiri dari 5 perlakuan dengan 3 kali ulangan. Bahan pakan terdiri dari beberapa bahan yang dapat dilihat paa Tabel 1. Berikut ini adalah perlakuan yang akan dilakukan: a) $100 \%$ tepung ikan dan $0 \%$ tepung keong mas, b) $75 \%$ tepung ikan dan $25 \%$ tepung keong mas, c) $50 \%$ tepung ikan dan $50 \%$ tepung keong mas, d) $25 \%$ tepung ikan dan $75 \%$ tepung keong mas, e) $0 \%$ tepung ikan dan $100 \%$ tepung keong mas.

Tabel 1. Komposisi bahan baku pakan (gram)

\begin{tabular}{llllll}
\hline \multirow{2}{*}{ Bahan Pakan } & \multicolumn{5}{c}{ Perlakuan } \\
\cline { 2 - 6 } & $\mathrm{A}$ & $\mathrm{B}$ & $\mathrm{C}$ & $\mathrm{D}$ & $\mathrm{E}$ \\
\hline Tepung ikan & 1126 & 844,5 & 563 & 281,5 & 0 \\
Tepung Keong mas & 0 & 281,5 & 563 & 844,5 & 1126 \\
Tepung kedelai & 563 & 563 & 563 & 563 & 563 \\
Tepung jagung & 511 & 511 & 511 & 511 & 511 \\
Tepung tapioka & 100 & 100 & 100 & 100 & 100 \\
Minyak ikan & 75 & 75 & 75 & 75 & 75 \\
Minyak jagung & 75 & 75 & 75 & 75 & 75 \\
Premix & 50 & 50 & 50 & 50 & 50 \\
\hline Total & 2500 & 2500 & 2500 & 2500 & 2500 \\
\hline
\end{tabular}

\section{Prosedur Penelitian \\ Pembuatan Tepung Keong Mas ( $P$. canicula)}

Keong mas dicuci dan direbus selama 30 menit, kemudian pengambilan daging, setalah itu daging dicuci kembali dan dipotong-potong untuk dijemur. Penjemuran dilakukan 2-3 hari di bawah panas matahari (dalam kondisi cuaca panas), setelah kering dilakukan penggilingan (tepung keong mas).

\section{Pembuatan Pakan}

Semua bahan yang sudah dipersiapkan lalu dicampur sesuai komposisi yang telah ditentukan dan kemudian dilakukan pencetakan (pellet). Selanjutnya pakan yang sudah dicetaak dijemur sampai pellet kering $( \pm$ 12 jam), kemudian disimpan di tempat yang kering (toples).

\section{Pelaksanaan Penelitian}

Ikan yang sudah dikalimatisasi ditebar dalam wadah penelitian sebayak 20 ekor per $25 \mathrm{~cm}$ air. Sebelum ikan dimasukan, dilakukan sampling awal pertumbuhan ikan nila gift. Pemeliharaan benih ikan nila gift dilakukan selama 56 hari dengan pemberian pakan sebanyak 5\% dari bobot tubuhnya. Pemberian pakan dilakukan tiga kali sehari yaitu pukul 06.00 WIB, pukul 13.00 WIB dan pada pukul 18.00 WIB. Selama pemeliharaan dilakukan penyiponan setiap pagi hari dan pergantian air sebanyak $20 \%$ dari total volume air di akuarium untuk membersihkan sisa pakan dan feses.

\section{Parameter Penelitian}

\section{Laju Pertumbuhan Harian}

Laju pertumbuhan harian dihitung dengan menggunakan rumus:

Keterangan :

$$
G R=\frac{W_{t}-W_{0}}{t}
$$

GR : Laju pertumbuhan harian (g/hari).

$\mathrm{W}_{\mathrm{t}}$ : Berat rata-rata ikan pada hari ke-t $(\mathrm{g})$.

$\mathrm{W}_{\mathrm{o}}$ : Berat rata-rata ikan pada hari ke-0 $(\mathrm{g})$.

t : Waktu (hari)

\section{Efisiensi Pakan (EP)}

Efisiensi pakan menunjukkan kualitas makanan yang diberikan, menurut Zonneveld (1991) dapat dihitung dengan menggunakan rumus sebagai berikut:

$E p=\frac{\left(W_{t}+W_{d}\right)-W_{0}}{F} \times 100 \%$ 
Keterangan:

Ep : Efisiensi pakan (\%)

$\mathrm{F}$ : Jumlah pakan yang habis selama masa pemeliharaan $(\mathrm{g})$

Wt : Berat ikan pada akhir pemeliharaan $(\mathrm{g})$

Wo : Berat ikan pada awal pemeliharaan $(\mathrm{g})$

Wd : Bobot ikan mati (g)

\section{Kualitas Air}

Pengukuran kualitas air dilakukan setiap hari. Pengukuran diamati pada pagi, siang, dan sore. Pengukuran kualitas air dilakukan secara in situ yaitu suhu, $\mathrm{DO}, \mathrm{pH}$.

\section{Analisis Data}

Data pertumbuhan ikan nila gift $(O$. niloticus) yang diperoleh dianalisis dengan analisis sidik ragam. Apabila hasil uji antara perlakuan berbeda nyata maka akan dilanjutkan dengan uji BNT (beda nyata terkecil) pada selang kepercayaan 95\% (Hanafiah, 2010). Alat bantu pengolahan data statistik menggunakan program microsoft office excel.

\section{HASIL DAN PEMBAHASAN}

\section{Pertumbuhan Laju Harian}

Pertumbuhan harian benih ikan nila gift (Oreochromis niloticus) selama 56 hari masa pemeliharaan. Laju pertumbuhan harian (Gambar 1) yang paling tinggi adalah pada perlakuan C (0,19 g/hari) dan perlakuan D dan perlakuan $\mathrm{E}$ menunjukkan nilai yang sama $(0,18 \mathrm{~g} /$ hari). Sedangkan pada perlakuan A $(0,17 \mathrm{~g} /$ hari $)$ dan perlakuan $\mathrm{B}$ menunjukkan nilai $(0,16 \mathrm{~g} / \mathrm{hari})$, yang merupakan nilai laju pertumbuhan terendah dari semua perlakuan (Gambar 1). Berdasarkan data laju pertumbuhan harian yang diperoleh, tingkat substitusi tepung keong mas sebesar 0\% (perlakuan A), 25\% (perlakuan B), 50\% (perlakuan C), 75\% (perlakuan D), dan 100\% (perlakuan E) tidak berbeda nyata terhadap laju pertumbuhan benih ikan nila gift selama penelitian. Hal ini berarti tepung keong mas dapat digunakan untuk mensubstitusi tepung ikan dari tingkat substitusi 25\% hingga 100\%.

Berdasarkan uji statistik, perlakuan tepung ikan dengan subtitusi tepung keong mas dalam pakan tidak memberikan pengaruh nyata terhadap laju pertumbuhan harian benih ikan nila gift pada tingkat selang kepercayaan 95\%. Dari hasil uji BNT menunjukkan bahwa perlakuan A berbeda nyata terhadap perlakaun
B, perlakuan C, perlakuan D, dan perlakuan E, sedangkan perlakauan D dan perlakuan E tidak berbeda nyata. Dalam penelitian Gustiano (2004) benih ikan nila gift yang diberi pelet komersil selama masa pemeliharaan 30 hari menghasilkan laju pertumbuhan harian 0,2 \pm $0,02 \mathrm{~g} / \mathrm{hari}$.

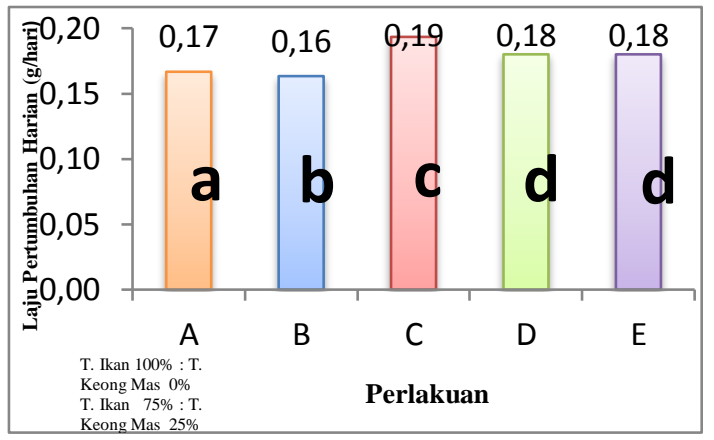

Gambar 1. Grafik laju pertumbuhan harian benih ikan nila gift (Oreochromis niloticus)

\section{Efisiensi Pakan}

Setelah mengalami masa pemeliharaan tertentu respon ikan terhadap pemberian pakan dapat diketahui dengan mengevaluasi pemberian pakan. Istilah yang umum digunakan untuk mengevaluasi pakan adalah efisiensi pakan. Tingkat konsumsi pakan benih ikan nila gift dan grafik efesiensi pakan selama 56 hari masa pemeliharaan seperti yang disajikan pada Gambar 2.

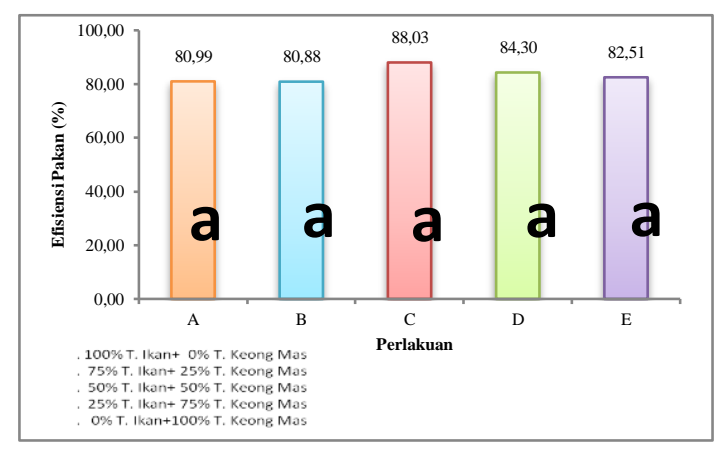

Gambar 2. Grafik efisiensi pakan benih ikan nila gift (Oreochromis niloticus)

Efisiensi pakan adalah perbandingan antara pertambahan bobot ikan dengan jumlah pakan yang habis selama masa pemeliharaan tertentu yang dinyatakan dalam persen. Efisensi pakan menunjukkan kualitas makanan yang diberikan, efisiensi pakan yang dimanfaatkan oleh ikan bergantung pada jenis 
dan jumlah pakan yang diberikan, spesies, ukuran ikan, dan kualitas air. Nilai efisiensi pakan yang cukup baik selama penelitian ini disebabkan jenis bahan pakan yang digunakan dalam penelitian ini menghasilkan pakan yang mudah dicerna oleh benih nila. Salah satu faktor yang mempengaruhi kecernaan pakan adalah kandungan serat kasar. Zonneveld, et al., (1991) menyatakan bahwa serat kasar mempunyai nilai nutrisi yang sangat rendah, namun dalam jumlah tertentu disarankan penggunaannya untuk mempercepat gerak peristaltik usus dan penggumpalan kotoran.

Nila yang termasuk jenis tilapia tidak dapat mencerna bahan pakan yang mengandung serat kasar yang tinggi. Apabila kandungan serat kasar terlalu tinggi dalam pakan maka akan mempercepat pakan melewati usus, sehingga nutrisi yang diserap menjadi berkurang dan pada akhirnya akan menyebabkan rendahnya protein yang diserap oleh tubuh benih nila. Kandungan serat kasar pada proporsi pakan dengan persentase tepung ikan berbeda disubtitusikan tepung keong mas 0\% (perlakuan A) yaitu 80,99\%, tepung keong mas 25\% (perlakuan B) yaitu $80,88 \%$ merupakan efesiensi pakan yang terendah dari perlauan yang ada. Tepung keong mas 50\% (perlakuan C) yaitu $88,03 \%$ merupakan efesiensi pakan yang paling tinggi. Tepung keong mas $75 \%$ (perlakuan D) yaitu 84,30 dan tepung keong mas $100 \%$ (perlakuan E) yaitu 81,17 , yang masih dalam batas optimum kebutuhan serat kasar bagi benih nila. Berdasarkan hal ini makin tinggi nilai efisiensi pakan maka respon ikan terhadap pakan tersebut makin baik, yang ditunjukkan antara lain dengan makin cepatnya pertumbuhan ikan.

Sahwan (2003) menyatakan bahwa kebutuhan serat kasar bagi benih nila berkisar antara 6-8\%. Djajasewaka (1985) menyatakan bahwa kandungan serat kasar lebih dari $8 \%$ dalam pakan dapat menurunkan kualitas struktur pakan. Tingkat konsumsi pakan juga diduga ada hubungannya dengan preferensi atau tingkat kesukaan ikan terhadap pakan yang diberikan, yaitu dalam hal warna dan aroma. NRC (1983) menyatakan bahwa nilai nutrisi pakan boleh jadi merupakan permasalahan utama, tetapi yang terpenting adalah tingkat penerimaan pakan oleh ikan. Tingkat konsumsi pakan juga diduga ada hubungannya dengan preferensi atau tingkat kesukaan ikan terhadap pakan yang diberikan, yaitu dalam hal warna dan aroma. NRC (1983) menyatakan bahwa nilai nutrisi pakan boleh jadi merupakan permasalahan utama, tetapi yang terpenting adalah tingkat penerimaan pakan oleh ikan.

\section{Kualitas Air}

Hasil pengamatan kualitas air yang diperoleh masih dalam tahap toleransi untuk pemeliharaan benih ikan nila gift (Oreochromis niloticus). Kisaran suhu selama penelitian antara $25,4-30,7^{\circ} \mathrm{C}$ dan kisaran DO berkisar antara 4,28-7,12 ml/L sementara $\mathrm{pH}$ berada pada kisaran 6-7. Pengamatan kualitas air selama penelitian dapat dilihat pada Tabel 3.

Tabel 3. Hasil pengamatan kualitas air

\begin{tabular}{llll}
\hline Perlakuan & Suhu $\left({ }^{\circ} \mathrm{C}\right)$ & $\mathrm{DO}(\mathrm{ml} / \mathrm{L})$ & $\mathrm{pH}$ \\
\hline Perlakuan A $(100 \% ; 0 \%)$ & $25,6-29,8$ & $4,28-7,12$ & $6-7$ \\
Perlakuan B $(75 \% ; 25 \%)$ & $26,0-30,5$ & $4,42-7,08$ & $6-7$ \\
Perlakuan C $(50 \% ; 50 \%)$ & $26,5-30,7$ & $4,52-6,50$ & $6-7$ \\
Perlakuan D $(25 \% ; 75 \%)$ & $25,4-29,8$ & $4,25-7,06$ & $6-7$ \\
Perlakuan E (0\%; 100\%) & $25,8-30,2$ & $4,37-6,75$ & $6-7$ \\
\hline
\end{tabular}

\section{KESIMPULAN}

Pemeliharaan benih ikan nila gift (Oreochromis niliticus) dengan perlakuan 50 $\%$ tepung ikan dan $50 \%$ tepung keong mas memberikan hasil paling baik terhadap pertumbuhan harian dan efisensi pakan ikan nila gif.

\section{DAFTAR PUSTAKA}

Craig, S., L.A.Helfrich. 2009. Understanding Fish Nutrition, Feed, and Feeding. Virgina Cooperation extension. Publication 420-256.

Zonneveld, N., E. A. Huisman., and J. H. Boon. 1991. Prinsip-prinsip Budidaya Ikan. PT. Gramedia Pustaka Utama, Jakarta. $318 \mathrm{hlm}$.

Gustiano, R. 2004. Growth Rate Comparison of Three Color Morphs of Common Carp (Cyprinus carpio L) Cultured in Commercial Floating Net Cages. Zuriat 15: $178-186$.

Sahwan, M. F. 2003. Pakan Ikan dan Udang, Formulasi, Pembuatan, Analisis Ekonomi. Penebar Swadaya, Jakarta. 96 hlm. 
Djajasewaka, H. 1985. Pakan Ikan. Cetakan ke-1. Yasaguna, Jakarta. $47 \mathrm{hlm}$.
National Research Council (NRC). 1983. Nutrient Requirement of Warmwater Fishes. National Academy Press, Washington DC. $71 \mathrm{hlm}$ 